\title{
Pemberdayaan Siswa dalam Melawan Pandemi COVID-19 dengan Meningkatkan Imunitas Fisik di SMK Ar-Rohman Tegalrejo Kabupaten Magetan
}

\author{
*Dian Anisia Widyaningrum, Aris Hartono, Bagas Wahyu Setiawan \\ Program Studi S1 Keperawatan \\ Sekolah Tinggi Ilmu Kesehatan Bhakti Husada Mulia Madiun, Indonesia
}

\begin{abstract}
ABSTRAK
Pandemi COVID-19 saat ini telah menjadi perhatian di dunia termasuk di Indonesia. Dimana pandemi COVID-19 merupakan bencana non alam yang dapat memberikan dampak pada kondisi kesehatan fisik dan jiwa setiap orang. Dengan adanya kondisi new normal, maka masyarakat termasuk siswa yang bersekolah sudah dapat beraktifitas kembali. Upaya pencegahan penyebaran infeksi dapat dilakukan dengan menjalankan protokol kesehatan dengan 5M seperti memakai masker, menjaga jarak, mencuci tangan, membatasi mobilitas, dan menjauhi kerumunan. Selain itu, salah satu upaya yang dapat dilakukan untuk mencegah penyebaran virus corona adalah dengan meningkatkan dan menjaga daya tahan (imunitas) tubuh. Menjaga imunitas atau daya tahan tubuh merupakan salah satu cara yang dapat dilakukan agar terhindar dari infeksi virus dan penyakit termasuk Covid-19. Namun demikian terbatasnya informasi khususnya dalam menjaga dan meningkatkan imunitas tubuh, maka diperlukan sosialisasi pada siswa akan pentingnya imunitas tubuh di masa pandemi ini. Tujuan pengadian masayarakat ini adalah untuk pemberdayaan siswa dalam meningkatan imunitas fisik di sekolah. Metode pelaksanaan pengabdian masyarakat ini terdiri dari tiga tahap yaitu tahap persiapan, pelaksaanaan, dan evaluasi. Pada tahap pelaksanaan diberikan edukasi tentang cara meningkatkan imunitas fisik dalam melawan pandemi COVID-19. Hasil pengabdian masyarakat, siswa telah memperoleh pengetahuan yang baik tentang cara meningkatkan imunitas fisik selama pandemi COVID-19. Promosi kesehataan untuk meningkatkan imunitas fisik siswa sekolah direkomendasikan untuk dilakukan sebagai bentuk kerjasama Dinas Kesehatan dan Dinas Pendidikan Kebudayaan dengan tetap menjalankan protokol kesehatan di sekolah.
\end{abstract}

Kata kunci : Imunitas Fisik, Siswa Sekolah, Pandemi COVID-19

\section{PENDAHULUAN}

Melihat kondisi saat ini di tahun 2020, Indonesia merupakan salah satu negara yang terkena pandemi Virus Corona yakni COVID-19. Adanya COVID-19 banyak membawa perubahan dan kebiasaan terhadap aktivitas masyarakat baik dari segi ekonomi maupun politik, bahkan dalam dunia pendidikan. Banyak negara memutuskan untuk sementara menutup sekolah, kampus selama masa pandemi COVID-19 berlangsung. Setiap Negara membuat kebijakan-kebijakan untuk mengatasi permasalahan yang sedang terjadi. Untuk mengatasi wabah pandemi COVID-19 semua negara menerapkan sebuah tindakan salah satunya dengan melakukan gerakan social distancing yaitu jarak sosial yang dirancang untuk mengurangi interaksi orang-orang dalam komunitas yang lebih luas (Wilder-Smith \& Freedman, 2020). Saat new normal seharusnya seluruh 
masyarakat melaksanakan social distancing yaitu pembatasan kegiatan sosial, seperti bekerja dari rumah dan untuk siswa belajar di rumah. Namun daerah yang berada pada zona kuning dan hijau boleh melakukan tatap muka asalkan menerapkan protokol kesehatan yang ketat. Menteri Pendidikan dan Kebudayaan Nadiem Anwar Makarim mengatakan bahwa sekalipun sekolah di zona hijau dan kuning yang ingin melakukan tatap muka maka harus mendapat persetujuan dari orangtua siswa dan komite sekolah.

COVID-19 merupakan penyakit yang saat ini menjadi pertama di Indonesia. COVID-19 adalah penyakit yang disebabkan virus Sars-Cov-2 dan ditularkan antara manusia. Penularan virus korona dari manusia ke manusia dapat terjadi melalui kontak erat dan droplet, tidak melalui udara. Upaya pencegahan dapat dilakukan dengan menjalankan protokol kesehatan seperti menjaga jarak, cuci tangan secara teratur dan menjaga etika ketika batuk dan bersin (Kemenkes RI, 2020). Protokol kesehatan di sekolah merupakan aturan untuk mencegah meluasnya penyebaran penyakit COVID-19 yang diakibatkan virus corona di institusi pendidikan. Selain itu, salah satu upaya yang dapat dilakukan untuk mencegah penyebaran virus corona adalah dengan meningkatkan dan menjaga daya tahan (imunitas) tubuh.

Imunitas atau daya tahan tubuh merupakan suatu reaksi dalam tubuh terhadap bahan asing yang masuk ke dalam tubuh secara molekuler atau seluler (Alkandahri dkk, 2018). Daya tahan tubuh merupakan salah satu faktor yang mempengaruhi kemampuan tubuh untuk mempertahankan kondisi tubuh dalam melawan penyakit, terutama penyakit yang disebabkan oleh virus. Beberapa upaya dapat dilakukan untuk meningkatkan imunitas fisik. Menurut Pedoman Dukungan Kesehatan Jiwa dan Psikososial Pada Masa Pandemi COVID-19, promosi kesehatan yang dapat dilakukan untuk meningkatkan imunitas fisik adalah dengan 5 cara yaitu 1) Makanan seimbang (karbohidrat, protein, sayur, buah-buahan yang mengandung vitamin dan mineral), jika diperlukan tambahan vitamin; 2) Minum yang cukup, orang dewasa minimal 2 liter per hari; 3) Olah raga minimal 30 menit sehari; 4) Berjemur di pagi hari seminggu dua kali; 5) Tidak merokok dan tidak minum alkohol (Kemkes, 2020).

Dalam rangka ikut mensosialisasikan dan mengedukasi masyarakat agar dapat melawan penyebaran infeksi virus corona, maka Prodi Keperawatan STIKES Bhakti Husada Mulia melaksanakan kegiatan pengabdian masyarakat melalui edukasi kesehatan dengan tetap mematuhi protokol kesehatan dengan judul : Pemberdayaan Siswa Dalam Melawan Pandemi COVID-19 Dengan Meningkatkan Imunitas Fisik di SMK Ar-Rohman Tegalrejo Kabupaten Magetan. Kegiatan tersebut dilakukan dalam beberapa rangkain mulai dari edukasi, tanya jawab, dan pemberian handsainitizer dan masker kepada siswa dengan pemberian secara simbolis.

\section{METODE}

Pengabdian masyarakat ini dilaksanakan di SMK Ar-Rohman Tegalrejo Kabupaten Magetan. Program ini ditujukan kepada siswa kelas 1 dan 2 sejumlah 28 siswa. Pelaksanaan pengadian masyarakat ini terdiri dari tiga tahap yaitu tahap persiapan, pelaksaanaan, dan evaluasi. Tahap persiapan dimulai dengan survey tempat pelaksanan kegaiatan, pembuatan proposal dan penyelesaian administrasi perijinan tempat atau lokasi pengadian masyarakat, dan pembuatan 
media promosi kesehatan. Tahap pelaksanaan dengan melakukan edukasi kesehatan tentang cara meningkatan imunitas fisik di masa pandemi COVID-19 dengan 5 cara yaitu 1) Makanan seimbang (karbohidrat, protein, sayur, buahbuahan yang mengandung vitamin dan mineral), jika diperlukan tambahan vitamin; 2) Minum yang cukup, orang dewasa minimal 2 liter per hari; 3) Olah raga minimal 30 menit sehari; 4) Berjemur di pagi hari seminggu dua kali; 5) Tidak merokok dan tidak minum alkohol. Tahap evaluasi pelaksanaan program bertujuan untuk mengukur tingkat pengetahuan siswa dalam meningkatkan imunitas fisik di masa pandemi COVID-19.

\section{HASIL DAN PEMBAHASAN}

Hasil kegiatan pengabdian masyarakat ini menunjukkan sebagian besar usia siswa adalah 16 tahun (50\%) dan berdasarkan data jenis kelamin terbanyak adalah perempuan $(57,14 \%)$. Pada data tingkat pengetahuan siswa tentang cara meningkatkan imunitas fisik setelah dilaksanakan program ini sebagian besar baik $(75 \%)$ sehingga program ini dapat dilakukan kembali pada siswa sekolah lainnya (Tabel 1).

Tabel 1

Data Umum Siswa

\begin{tabular}{lcc}
\hline Data Umum & Frekuensi (n) & Persentase (\%) \\
\hline Jenis Kelamin & 12 & 42,86 \\
Laki-laki & 16 & 57,14 \\
Perempuan & 28 & 100 \\
Jumlah & & \\
Usia Anak & 3 & 10,71 \\
15 tahun & 14 & 50 \\
16 tahun & 11 & 39,29 \\
17 tahun & 28 & 100 \\
Jumlah & & \\
\hline
\end{tabular}

Sumber: Data Diolah

Tabel 2

Data Pengetahuan Siswa Tentang Cara Meningkatkan Imunitas Fisik

\begin{tabular}{ccc}
\hline Tingkat Pengetahuan & Frekuensi (n) & Persentase $(\%)$ \\
\hline Baik & 21 & 75 \\
Cukup & 7 & 25 \\
Kurang & - & - \\
Jumlah & 58 & 100 \\
\hline
\end{tabular}

Sumber: Data Diolah 


\section{Pembahasan}

Kegiatan pengabdian kepada masyarakat yang dilakukan berupa edukasi kesehatan mengenai sosialisasi upaya peningkatan imunitas fisik siswa pada masa pandemi COVID-19 di SMK Ar-Rohman Tegalrejo Kabupaten Magetan telah dilaksanakan dengan lancar dan baik. Pada hari pelaksanaan kegiatan pengabdian kepada masyarakat diikuti kurang lebih 28 siswa dari kelas 1 dan 2 SMK Ar-Rohman. Kegiatan pengabdian kepada masyarakat dimulai pukul 09.00 WIB di ruang kelas yang dilaksanakan oleh panitia pengabdian kepada masyarakat yang terdiri dari dua orang dosen dan perwakilan mahasiswa sebanyak tiga orang Prodi Keperawatan STIKES Bhakti Husada Mulia Madiun. Kegiatan pengabdian kepada masyarakat ini dilaksanakan dengan mengikuti protokol kesehatan dimana peserta, tim dosen, dan mahasiswa kegiatan diwajibkan menggunakan masker, menjaga jarak, dan mencuci tangan untuk menghindari penularan covid-19. Kegiatan ini terdiri dari 2 sesi acara yaitu sesi pemaparan materi selama \pm 30 menit dan diskusi selama 20 menit.

Pada sesi penyuluhan materi tim pelaksana memberikan sosialisasi atau edukasi kesehatan tentang cara meningkatan imunitas fisik di masa pandemi COVID-19 dengan 5 cara yaitu 1) Makanan seimbang (karbohidrat, protein, sayur, buah-buahan yang mengandung vitamin dan mineral), jika diperlukan tambahan vitamin; 2) Minum yang cukup, orang dewasa minimal 2 liter per hari; 3) Olah raga minimal 30 menit sehari; 4) Berjemur di pagi hari seminggu dua kali; 5) Tidak merokok dan tidak minum alkohol. Setelah sesi penyuluhan kemudian dilanjutkan dengan sesi demonstrasi cuci tangan yang benar dan menggunakan masker yang benar.

Dari hasil pengamatan yang dilakukan oleh panitia bahwa peserta sangat antusias dengan kegiatan pengabdian kepada masyarakat ini dikarenakan berkaitan dengan peningkatan imunitas tubuh dimana sangat diperlukan untuk mencegah terpaparnya virus COVID-19. Ada beberapa peserta yang telah melakukan berbagai upaya peningkatan imunitas fisik baik di rumah maupun di sekolah. Namun ada juga peserta yang belum mengetahui pentingnya imunitas tubuh dan belum tahu cara meningkatkan imunitas fisik di masa pandemi COVID-19. Dalam sesi diskusi dan tanya jawab peserta memberikan beberapa pertanyaan yang sangat antusias. Pertanyaannnya berkaitan dengan seberapa penting imunitas tubuh pada masa pandemi COVID-19 dan pertanyaan yang berkaitan dengan cara mencuci tangan dan memakai masker yang benar. Dengan adanya pemaparan ini, masyarakat terlihat lebih paham dan mengerti akan pentingnya menerapkan protokol kesehatan dan meningkatkan imunitas tubuh pada masa pendemi COVID-19 ini di SMK Ar-Rohman Tegalrejo Kabupaten Magetan.

Berdasarkan evaluasi program pengabdian masyarakat, tingkat pengetahuan siswa tentang cara meningkatkan imunitas fisik sebagian besar dalam kategori baik setelah dilakukan edukasi kesehatan. Menurut Mubarak, dkk (2009) pendidikan kesehatan adalah proses perubahan sikap dan perilaku seseorang atau individu yang dinamis, dimana perubahan tersebut tidak hanya dipengaruhi oleh transfering materi dari seseorang ke orang lain, namun perubahan tersebut bisa terjadi karena adanya kesadaran dalam diri individu, kelompok, dan masyarakat. Hal ini didukung pernyataan Budiman (2013) bahwa pengalaman pribadi dan informasi merupakan faktor yang dapat mempengaruhi 
pengetahuan dan sikap seseorang. Effendi (2009) yang mengatakan bahwa penerimaan perilaku yang didasari dengan pengetahuan dan sikap yang positif, maka perilaku tersebut akan bertahan lama. Tapi sebaliknya, jika perilaku yang tidak didasari dengan pengetahuan dan sikap yang positif maka perilaku tersebut tidak bertahan lama.

Pengabdian kepada masyarakat di SMK Ar-Rohman Tegalrejo Kabupaten Magetan yang memperoleh hasil tidak hanya pada peningkatan pengetahuan siswa terkait cara meningkatkan imunitas fisik, tapi dari hasil evaluasi diketahui bahwa siswa sudah dapat secara mandiri melakukan peningkatan imunitas fisik seperti berjemur, berolahraga, dan makan makanan yang bergizi. Dari hasil wawancara dengan beberapa siswa bahwa setelah dilakukan edukasi ini, siswa senang mendapat tambahan ilmu terkait melakukan protokol kesehatan seperti memakai masker yang benar dan mencuci tangan yang benar. Edukasi tentang cara meningkatkan imunitas fisik melawan pandemi COVID-19 sangat efektif untuk memberikan wawasan bagi masyarakat khususnya siswa SMK ArRohman Tegalrejo Kabupaten Magetan tentang hal-hal yang harus dilakukan dan tidak boleh dilakukan di masa pandemi ini. Hal ini juga perlu dukungan dari orangtua dan guru di sekolahnya, karena peranan orangtua dan guru sangat bermanfaat dalam mendukung anak yang telah memiliki sikap baik dan mengarahkan anak untuk mengubah sikap yang baik dalam kesehatan.

\section{SIMPULAN}

Sosialisasi atau edukasi tentang cara meningkatkan imunitas fisik melawan pandemi COVID-19 berpengaruh terhadap peningkatan pengetahuan siswa SMK Ar-Rohman. Dan kegiatan pengabdian masyarakat "Pemberdayaan Siswa Dalam Melawan Pandemi COVID-19 Dengan Meningkatkan Imunitas Fisik di SMK Ar-Rohman Tegalrejo Kabupaten Magetan" merupakan suatu sarana bagi dosen, mahasiswa, dan masyarakat untuk menjembatani ilmu keperawatan kepada masyarakat dan suatu bentuk pemberdayaan masyarakat dalam upaya meningkatkan imunitas fisik siswa melawan pandemi COVID-19. Dan diharapkan instansi pendidikan dan klinisi aktif dalam meningkatkan pengetahuan siswa di berbagai tingkatan sekolah dengan menggunakan berbagai media edukasi yang menarik bagi siswa sekolah. Serta harapannya kegiatan ini bisa secara kontinyu dilakukan sebagai bentuk kerjasama Dinas Kesehatan dan Dinas Pendidikan Kebudayaan pada tatanan pelayanan kesehatan di masyarakat.

\section{DAFTAR PUSTAKA}

Alkandahri MY, Subarnas A, Berbudi A. 2018. Review: Aktivitas Immunomodulator Tanaman Sambiloto (Andrographis 14aniculate Nees). Farmaka, 16(3), 16-21

Budiman \& Riyanto A. 2013. Kapita Selekta Kuisioner Pengetahuan Dan Sikap Dalam Penelitian Kesehatan. Jakarta : Salemba Medika. 
Effendi, Muh. Arief. 2009. The Power Of Corporate Governance: Teori dan Implementasi. Jakarta: Salemba Empat.

Kementrian Kesehatan. (2020). Pedoman Dukungan Kesehatan Jiwa dan Psikososial Pada Pandemi COVID-19. https://infeksiemerging.kemkes.go.id/download/Pedoman_Dukungan_K esehatan_Jiwa_dan_Psikososial_pada_Pandemi_COVID19.pdf. Diakses 20 Mei 2021.

Kementrian Kesehatan. (2020). Situasi Terkini Perkembangan Coronavirus Disease (COVID-19). https://covid19.kemkes.go.id/situasiinfeksiemerging/info-corona-virus/situasi-terkini-perkembangancoronavirusdisease-covid. Diakses 20 Mei 2021.

Mubarak, W, I \& Chayatin, N (2009). Ilmu Keperawatan Komunitas Pengantar dan Teori. Jakarta : Salemba Medika.

Wilder-Smith, A., \& Freedman, D. O. (2020). Isolation, quarantine, social distancing and community containment: pivotal role for old-style public health measures in the novel coronavirus $(2019-\mathrm{nCoV})$ outbreak. Journal of Travel Medicine, 1-4. 